\title{
STUDIES ON MARINE Streptomyces nigrifaciens (P-9). I. TAXONOMY AND STANDARDIZATION OF ANTIBIOTIC PRODUCTION
}

\section{ESTUDIOS SOBRE Streptomyces nigrifaciens (P-9) MARINO. I. TAXONOMIA Y ESTANDARIZACION DE PRODUCCION DE ANTIBIOTICO}

\author{
R. Balagurunathan \\ A. Subramanian \\ Centre of Advanced Study in Marine Biology \\ Annamalai University \\ Parangipettai 608502 \\ India
}

Recibido en enero de 1993; aceptado en agosto de 1993

\begin{abstract}
A strain of Streptomyces nigifaciens (p-9) was isolated from marine sediments. Morphological, cultural, biochemical and cell wall analyses were made to identify the strain. Glycerol, glucose, sucrose, lactose and maltose as carbon sources, and soybean meal, yeast extract, malt extract, peptone and sodium nitrate as nitrogen sources were used to select the best medium for maximum production of antibiotics. Glucose and soybean meal were the best carbon and nitrogen sources, respectively, for maximum antibiotic production. Ethyl acetate, n-butanol, dichloromethane, petroleum spirit and benzene were used for extraction. Ethyl acetate extract showed significant activity against both gram positive and gram negative bacteria. Streptonnyces nigiffaciens (p-9) differs significantly from the type strain in antibacterial activity.
\end{abstract}

\section{RESUMEN}

Se aisló una cepa de Streptomyces nigrifaciens (p-9) de sedimentos marinos. Para identificar la cepa, se hicieron análisis morfológicos, de cultivo, bioquímicos y de pared celular. A fin de seleccionar el mejor medio para lograr la máxima producción de antibiótico, se usaron glicerol, glucosa, sucrosa, lactosa y maltosa, como fuentes de carbono, y harina de soja, extracto de levadura, extracto de malta, peptona y nitrato de sodio, como fuentes de nitrógeno. Glucosa y harina de soja fueron las mejores fuentes de carbono y nitrógeno, respectivamente, para la mayor producción de antibiótico. En la extracción, se usaron acetato de etilo, n-butanol, diclorometano, éter de petróleo y benceno. El extracto de acetato de etilo mostró actividad significativa contra ambas bacterias, grampositiva y gramnegativa. Streptomyces nigrifaciens (p-9) difiere notablemente de la cepa tipo, en actividad antibacteriana.

\section{INTRODUCTION}

Marine microorganisms are one of the important sources of antibiotics and other biologically active substances. More than 300 new and unique antimicrobial and antitumor compounds were isolated from marine organisms (Okani, 1986). The actinomycetes are usually targeted because most of the micro-

\section{INTRODUCCION}

Los organismos marinos constituyen una de las fuentes importantes de antibióticos y otras substancias biológicamente activas. Más de 300 nuevos y únicos compuestos antimicrobianos $\mathrm{y}$ antitumorales han sido aislados de organismos marinos (Okami, 1986). Usualmente, los actinomicetos son objeto de estu- 
bially derived antibiotics and therapeutic drugs manufactured today are produced using members of this taxonomic group.

Some antibiotics such as Neomycin A and B (Sambamurthy and Ellaiah, 1974), Aplasmomycin and Istamycin A and B (Okami et al., 1976, 1979), Altemicidin (Takahashi et al., 1989), Tetrazomine (Suzuki et al., 1991) and $\alpha \beta$-unsaturated $y$-lactone antibiotic (Balagurunathan, 1992) are isolated from marine actinomycetes. In order to obtain novel and diverse collections of antagonistic actinomycetes, the sea sediments were routinely screened and a streptomycete strain p-9 was isolated. The strain showed significant antibacterial activity. Therefore, the present study was made to identify the strain and standardize a medium suitable for the naximum production of antibiotics.

\section{MATERIALS AND METHODS}

Sediment samples were collected from the littoral zone of Parangipettai, south India (Lat. 11029' N; Long. 79046' E), using Peterson grab. Isolation of streptomycetes was made following the method of Okazaki and Okami (1972). Morphological characters were studied with a compound microscope at a magnification of $600 x$, on cultures grown at $28^{\circ} \mathrm{C}$ for 7 to 14 days on yeast extract-malt extract agar (ISP medium-2) recommended by Shirling and Gottileb (1966). The spores and spore chains were studied with Scanning Electron Microscope (Hitachi S-450) at a magnification of 2,000x. Identification was done as per the ISP descriptions (Shirling and Gottileb, 1968) and Nonamura's (1974) key.

To determine the gross cultural characteristics of this organism, it was grown on a number of culture media (Waksman, 1961). The biochemical characteristics such as melanin production, gelatin liquefaction, nitrate reduction, starch hydrolysis and hydrogen sulfide production were studied. Utilization of carbon sources was studied as described by Shirling and Gottileb (1966). Cell wall analysis was made by the method of Becker et al. (1965).

To select the best carbon and nitrogen sources for optimum production of antibiotic, glycerol, glucose, sucrose, lactose and maltose $(1.0 \%)$ were used as carbon sources, and soybean meal, yeast extract, malt extract, pep- dio, porque la mayor parte de los antibióticos y fármacos derivados de microbios, fabricados en la actualidad, se producen usando miembros de este grupo taxonómico.

Algunos antibióticos como Neomicina A y B (Sambamurthy y Ellaiah, 1974), Aplasmomicina e Istamicina A y B (Okami et al., 1976, 1979), Altemicidina (Takahashi et al., 1989), Tetrazomina (Suzuki et al., 1991) y antibiótico de y-lactona a $\beta$-no saturado (Balagurunathan, 1992) se han aislado de actinomicetos marinos. Para obtener nuevas y variadas colecciones de actinomicetos antagónicos, se tamizaron periódicamente sedimentos marinos y se aisló una cepa p-9 de actinomiceto. La cepa mostró importante actividad antibacteriana. Por ello, se hizo el presente estudio con el fin de identificar la cepa y estandarizar un medio apropiado para lograr la máxima producción de antibiótico.

\section{MATERIALES Y METODOS}

Se recogieron muestras de la zona litoral de Parangipettai, al sur de la India (110 29'latitud N; 79०46'longitud E), usando draga de Peterson. Los estreptomicetos se aislaron siguiendo el método de Okazaki y Okami (1972). Los caracteres morfológicos se estudiaron con un microscopio compuesto a $600 \mathrm{x}$ de aumento, en cultivos que crecieron a $28^{\circ} \mathrm{C}$, de 7 a 14 días, sobre agar de extractos de malta y de levadura (medio 2, ISP) recomendado por Shirling y Gottileb (1966). Las esporas y cadenas de esporas se cstudiaron con un microscopio electrónico de barrido (Hitachi S-450) con aumento de $2,000 x$. La identificación se hizo siguiendo las descripciones de ISP (Shirling y Gottileb, 1968) y la clave de Nonamura (1974).

Para determinar las características de cultivo de este organismo, se le hizo crecer en varios medios de cultivo (Waksman, 1961). Se estudiaron las características bioquímicas, como producción de melanina, licuefacción de gelatina, reducción de nitrato, hidrólisis de almidones y producción de sulfurc de hidrógeno. La utilización de fuentes de carbono se estudió según la descripción de Shirling y Gottileb (1966). El análisis de pared celular se hizo con el método de Becker et al. (1965).

Con el fin de seleccionar las mejores fuentes de carbono y nitrógeno para la producción óptima de antibiótico, se usaron 
Balagurunathan and Subramanian: Studies on marine Streptomyces nigrifaciens (p-9)

tone and sodium nitrate $(1.0 \%)$ as nitrogen sources. As glucose and soybean were found to be the best sources of carbon and nitrogen, respectively, their effect on antibiotic activity was studied using concentrations ranging from 1.0 to $2.0 \%$.

The antibiotic production was studied in shake flasks at $28 \pm 1^{\circ} \mathrm{C}$ using soybean meal medium (soybean meal $1.5 \%$, glucose $1.5 \%$, sodium chloride $0.5 \%$, calcium carbonate $0.1 \%, \mathrm{pH} 7.0$ ). Fermentation was done according to Sambamurthy and Ellaiah (1974). The progress of antibiotic production during fermentation was monitored by the paper disc method using Bacillus subtilis. The maximum antibiotic titer was obtained $96 \mathrm{~h}$ after inoculation. 'The $\mathrm{pH}$ levels of the fermentation medium were noted daily. After $96 \mathrm{~h}$ of fermentation, the culture filtrate and mycelia were separated by centrifugation. Various solvents were used to determine the most suitable for extraction. The solvents n-butanol, ethyl acetate, dichloromethane, petroleum spirit and benzene were used for extraction. Different $\mathrm{pH}$ levels $(4,7$ and 10$)$ were used in the culture filtrate to test whether the extraction is dependent on $\mathrm{pH}$ value. About $5 \mathrm{ml}$ of the culture filtrate at each of the various $\mathrm{pH}$ values were extracted with $5 \mathrm{ml}$ of the solvents. The extracts were concentrated and tested against $B$. subtilis. Then the whole fermented broth was extracted with ethyl acetate at $\mathrm{pH} 7.0$. The extract was concentrated under reduced pressure at $40^{\circ} \mathrm{C}$ in a vacuum rotary evaporator, and tested against nine clinical isolates of bacteria and three fungal strains by paper disc method. Five-millimeter diameter filter paper discs impregnated with $0.5 \mathrm{mg}$ extract were used. The diameter of the inhibition zone was measured after $24 \mathrm{~h}$ of incubation at $37^{\circ} \mathrm{C}$ for bacteria and after $72 \mathrm{~h}$ of incubation at $28^{\circ} \mathrm{C}$ for fungi. The same method was applied for the fermentation of the type culture $S$. nigrifaciens (CBS-543.68) obtained from Centraalvoor schimmel cultures, The Baarn, Netherlands, for identification of $\mathrm{p}^{-9}$

\section{RESULTS AND DISCUSSION}

The sporophore is smooth with well developed substrate and aerial mycelia. The aerial mycelium is gray in colour; spore chains are Rectiflexibiles type (Fig. 1). Spore glicerol, glucosa, sucrosa, lactosa y maltosa (1.0\%), como fuentes de carbono, y harina de soja, extracto de levadura, extracto de malta, peptona y nitrato de sodio (1.0\%), como fuentes de nitrógeno. Glucosa y harina de soja resultaron las mejores fuentes de carbono y nitrógeno, respectivamente, por lo que se estudió su efecto en la actividad del antibiótico, usando concentraciones de 1.0 a $2.0 \%$.

Se estudió la producción de antibiótico en matraces con agitación a $28 \pm 1^{\circ} \mathrm{C}$, usando harina de soja como medio $(1.5 \%$ de harina de soja, $1.5 \%$ de glucosa, $0.5 \%$ de cloruro de sodio, $0.1 \%$ de carbonato de calcio, $7.0 \mathrm{de} \mathrm{pH}$ ). La fermentación se llevó a cabo de acuerdo con Sambamurthy y Ellaiah (1974). El progreso de la producción de antibiótico durante la fermentación se siguió con el método del disco de papel, usando Bacillus subtilis. La máxima dosis de antibiótico se obtuvo 96 horas después de la inoculación. Los niveles de $\mathrm{pH}$ del medio de fermentación se anotaron diariamente. Después de 96 horas de fermentación, el filtrado de cultivo y micelio se separaron mediante fuerza centrífuga. Se probaron varios solventes, para determinar el más apropiado para extracción, y se usaron con ese fin n-butanol, acetato de etilo, diclorometano, éter de petróleo y benceno. Se utilizaron diferentes niveles de $\mathrm{pH}(4,7$ y 10$)$ para el filtrado de cultivo, con objeto de probar si la extracción cra dependiente del valor del $\mathrm{pH}$. Se extrajo aproximadamente $5 \mathrm{ml}$ de filtrado de cultivo para cada uno de los diferentes valores de $\mathrm{pH}, \operatorname{con} 5 \mathrm{ml}$ de los soventes. Los extractos se concentraron y probaron contra $B$. subtilis. Luego, se extrajo todo el caldo de cultivo utilizando acctato de etilo con 7.0 de $\mathrm{pH}$. El extracto se concentró bajo presión reducida a $40^{\circ}$ en un evaporador rotativo, y se probó contra nueve aislamientos clínicos de bacterias y tres cepas de hongos, con el método del disco de papel. Se usaron discos de papel filtro, de $5 \mathrm{~mm}$ de diámetro, impregnados con $0.5 \mathrm{mg}$ de extracto. El diámetro de la zona de inhibición se midió después de 24 horas de incubación a $37^{\circ} \mathrm{C}$, para las bacterias, y después de 72 horas de incubación a $28^{\circ} \mathrm{C}$, para los hongos. El mismo método se aplicó para la fermentación del cultivo tipo $S$. nigrifaciens (CBS-543.68) obtenido de cultivos de Centraalvoor Schimmel, The Baam, Holanda, para identificación de p-9. 
surface is smooth (Fig. 2). Light brown or blackish pigments appeared in the culture medium. The cultural and physiological characteristics are shown in tables 1-3. This strain contains LL-diamino pimelic and glycine in the cell wall. According to the chemical composition, the strain belongs to cell wall type-I. As per Nonamura's (1974) key, the strain is assigned to gray (GY), melanoid pigment none $(0)$, reverse side pigment none $(0)$, soluble pigment present, Rectiflexibiles (RF) and smooth spore (SM) surface group. The morphological characteristics and cell wall type indicate that the strain belongs to the genus Streptomyces. Accordingly, a comparison of this strain was made with descriptions in ISP reports (Shirling and Gottileb, 1968) and Nonamura's (1974) key for identification. Strain No. p-9 resembles Streptomyces nigifaciens (ISP-5071). However, p-9 differs from $S$. nigrifaciens (CBS-543.68) by showing excellent growth in Czapek's agar and significant antibacterial activity against both gram positive and gram negative bacteria. It is appropriate, therefore, to classify $\mathrm{p}-9$ as a variant of $S$. nigrifaciens and designated as $S$. migifaciens $(\mathrm{p}-9)$.

The effect of different carbon and nitrogen sources on antibiotic production is presented in table 4. Glucose and soybean meal were the best carbon and nitrogen sources, respectively, for the maximum production of antibiotic and the maximum activity was seen in $1.5 \%$ of glucose and $1.5 \%$ of soybean meal (table 5). The use of slowly consumed carbon sources (starch and soybean oil) and nitrogen sources (soybean meal) has been reported to be effective for the production of various types of antibiotics of streptomycetes (Omurat al., 1980).

The antibiotic activity of $S$. nigrifaciens (p-9) during fermentation is shown in table 6. The maximum antibiotic titer was seen at $96 \mathrm{~h}$ of fermentation. The antibiotic activity then decreased with time. The metabolites are liberated into the medium after $48 \mathrm{~h}$ of fermentation and the production of these metabolites is activated in the late logarithmic to stationary stage (i.e. $96 \mathrm{~h}$ ) of fermentation, after cell division and biomass accumulation have largely ceased. The initial $\mathrm{pH}$ during fermentation was 7.0, increasing to 7.3 in $96 \mathrm{~h}$ and to 7.9 in $120 \mathrm{~h}$. Most antibiotic fermentations start at a pH close to neutrality, then rise to 8 or above as carbohydrates become

\section{RESULTADOS Y DISCUSION}

El esporoforo es suave con sustrato bien desarrollado y micelio aćreo. El micelio aéreo es de color gris; las cadenas de esporas son de tipo Rectiflexibiles (Fig. 1). La superficie de espora es suave (Fig. 2). En el medio de cultivo aparecieron pigmentos negruzcos o de color café claro. Las características de cultivo y fisiológicas se muestran en las tablas 1 a 3 . Esta cepa contiene ácido LL-diaminopimélico y glicina en la pared celular. De acuerdo con la composición quimica, la cepa pertenece al tipo I de pared celular. En cuanio a la clave de Nonamura (1974), la cepa se asigna al grupo gris (GY), sin pigmento melanoide (0), sin pigmento del lado inverso (0), con presencia de pigmento soluble, Rectiflexibiles (RF) y superficie suave de espora (SM). Las características morfológicas y el tipo de pared celular indican que la cepa perienece al género Streptomyces. En consecuencia, se hizo una comparación de esta cepa con las descripciones de los informes ISP (Shirling y Gottilcb, 1968) y la clave de Nonamura (1974), para identificarla. La cepa No. p-9 es similar a Streptomyces nigrifaciens (ISP-5071). Sin embargo, difiere de $S$. nigrifaciens (CBS-543.68) en que muestra excelente crecimiento en agar de Czapek $\mathrm{e}$ importante actividad antibacteriana contra bacterias grampositivas y gramnegativas. Por tanto, es apropiado clasificar a p-9 como una variante de $S$. nigrifaciens y nombrarla $S$. nigifaciens (p-9).

El efecto de diferentes fuentes de carbono y nitrógeno en la producción de antibiótico se presenta en la tabla 4. Glucosa y harina de soja fueron las mejores fuentes de carbono y nitrógeno, respectivamente, para la máxima producción de antibiótico; la actividad máxima se observó en $1.5 \%$ de glucosa y $1.5 \%$ de harina de soja (tabla 5). El uso de fucntes de carbono consumidas lentamente (almidón y aceite de soja) y de fuentes de nitrógeno (harina de soja) se ha considerado efectivo para producir varios tipos de antibióticos de estreptomicetos (Omura et al. 1980).

La actividad antibiótica de $S$. nigrifaciens (p-9) durante la fermentación, se muestra en la tabla 6. La máxima dosis de antibiótico se logró a las 96 horas de fermentación. La actividad antibiótica decreció luego con el tiempo. Los metabolitos son liberados en el medio después de 48 horas de 


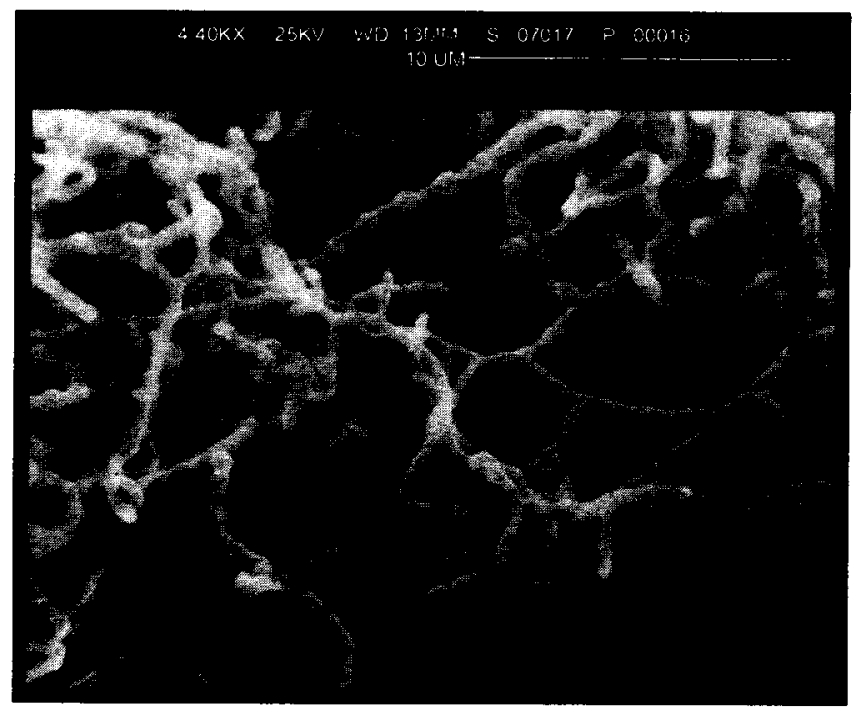

Figure 1. Aerial mycelium of strain p-9 $(400 x)$.

Figura 1. Micelio aéreo de cepa p-9 (400x).

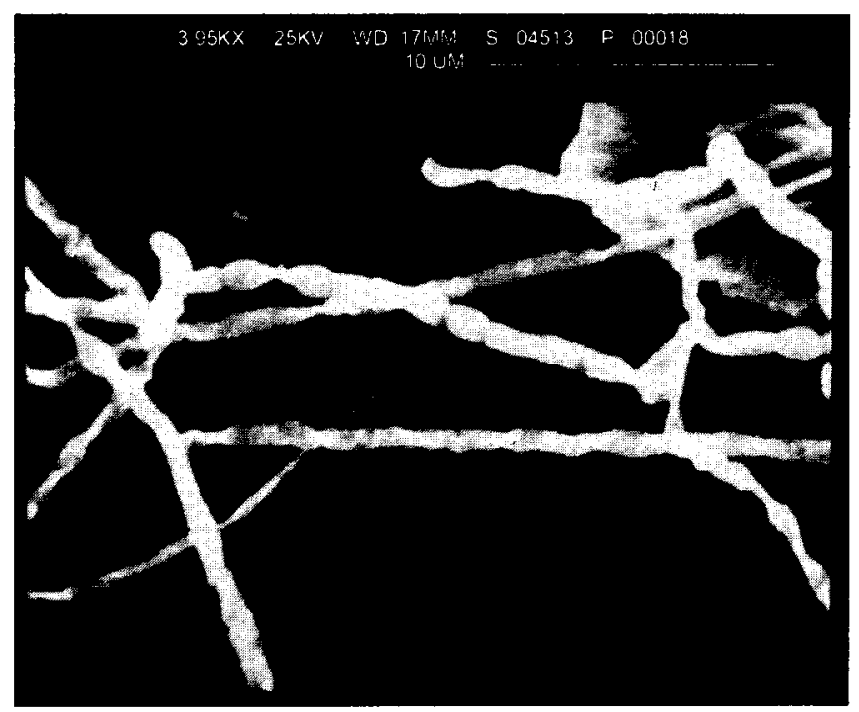

Figure 2. SEM of strain p-9 spores $(2,000 \mathrm{x})$.

Figura 2. Esporas de cepa p-9, a través de microscopio clectrónico de barrido $(2,000 \mathrm{x})$.

exhausted. Maximum antibiotic production often occurred during the earlier stage of this rise in $\mathrm{pH}$ level (Porter, 1975). The changes in acidity of the medium have a significant effect on the yield of the end products, which is presumably connected with the increase in fermentación y la producción de estos metabolitos se activa al final de la etapa logaritmica a estacionaria (i.e. 96 horas) de fermentación, después de que la división celular y la acumulación de biomasa ha cesado en gran parte. El pH inicial durante la fermentación 
Table 1. Cultural characteristics of strain p-9.

Tabla 1. Características de cultivo de la cepa p-9

\begin{tabular}{|c|c|c|c|c|c|}
\hline Medium & Growth & $\begin{array}{l}\text { Aerial } \\
\text { mycelium }\end{array}$ & $\begin{array}{l}\text { Substrate } \\
\text { mycelium }\end{array}$ & $\begin{array}{l}\text { Reverse } \\
\text { side }\end{array}$ & $\begin{array}{l}\text { Soluble } \\
\text { pigments }\end{array}$ \\
\hline Oatmeal agar & Good & Gray colour & Colourless & Yellow & None \\
\hline Yeast-malt agar & Moderate & Gray colour & Colourless & Pale yellow & Pale brown \\
\hline Czapek's Dox & Good & Gray & Colourless & $\begin{array}{l}\text { Brownish } \\
\text { black }\end{array}$ & $\begin{array}{l}\text { Brownish } \\
\text { black }\end{array}$ \\
\hline $\begin{array}{l}\text { Nutrient } \\
\text { Glucose agar }\end{array}$ & Moderate & $\begin{array}{l}\text { Gray to } \\
\text { whitish }\end{array}$ & Colourless & Light yellow & $\begin{array}{l}\text { Brownish } \\
\text { black }\end{array}$ \\
\hline $\begin{array}{l}\text { Glucose } \\
\text { Asparagine agar }\end{array}$ & Moderate & Whitish gray & Colourless & Light yellow & None \\
\hline $\begin{array}{l}\text { Dextrose peptone } \\
\text { yeast extract }\end{array}$ & Good & Gray & $\begin{array}{l}\text { Colourless } \\
\text { to yellowish }\end{array}$ & Pale yellow & $\begin{array}{l}\text { Light brownish } \\
\text { black }\end{array}$ \\
\hline Egg albumin & Poor & Light gray & Colourless & None & None \\
\hline Starch agar & Poor & Whitish gray & Colourless & None & None \\
\hline
\end{tabular}

Table 2. Physiological characteristics of strain p-9.

Tabla 2. Características fisiológicas de la cepa p-9.

\begin{tabular}{llll}
\hline Melanin production & Negative & Starch hydrolysis & Positive \\
$\mathrm{H}_{2} \mathrm{~S}$ production & Positive & Gelatin liquefaction & Positive \\
Indole production & Positive & Nitrate reduction & Positive \\
\hline
\end{tabular}

Table 3. Utilization of carbon compounds by strain p-9.

Tabla 3. Utilización de compuestos de carbono por la cepa p-9.

\begin{tabular}{lcll}
\hline D-Glucose & + & Fructose & + \\
Arabinose & + & Sucrose & - \\
Xylose & + & Raffinose & - \\
Inositol & - & Rhamnose & + \\
Mannitol & + & & \\
\hline
\end{tabular}

ammonium and nitrogen due to decomposition of soja proteins and autolysis of the mycelium (Egorov, 1985). Among the solvents used, the ethyl acetate extract showed the maximum activity at $\mathrm{pH} 7.0$. The other solvent extracts showed very weak activity. The extraction was dependent on $\mathrm{pH}$ as there is no activity at other $\mathrm{pH}$ than 7.0 . fue 7.0, se incrementó a 7.3 en 96 horas y a 7.9 en 120 horas. La fermentación en la mayoría de los antibióticos comienza con un $\mathrm{pH}$ cercano a la neutralidad, luego sube a 8 o más, según se van agotando los carbohidratos. La máxima producción de antibiótico ocurre frecuentemente durante la etapa más temprana de esta elevación del nivel de $\mathrm{pH}$ 
Balagurunathan and Subramanian: Studies on marine Strepromyces nigrifociens (p-9)

Table 4. Effect of various carbon and nitrogen sources on the antibiotic activity against Bacillus subtilis.

Tabla 4. Efecto de varias fuentes de carbono y nitrógeno sobre la actividad antibiótica contra Bacillus subtilis.

\begin{tabular}{|c|c|c|c|}
\hline $\begin{array}{c}\text { Carbon sources } \\
(1.0 \%)\end{array}$ & $\begin{array}{l}\text { Inhibition zone } \\
\qquad(\mathrm{mm})\end{array}$ & $\mathrm{N}_{2}$ sources & $\begin{array}{l}\text { Inhibition zone } \\
\qquad(\mathrm{mm})\end{array}$ \\
\hline Glycerol & 8 & Soybcan meal & 16 \\
\hline Glucose & 14 & Yeast extract & 10 \\
\hline Sucrose & 8 & Malt extract & 11 \\
\hline Lactose & 6 & Peplone & 9 \\
\hline Maltose & 9 & Sodium nitrate & 8 \\
\hline
\end{tabular}

Table 5. Effect of various concentrations of glucose and soybean meal on antibiotic activity.

Tabla 5. Efecto de varias concentraciones de glucosa y harina de soja sobre la actividad antibiótica.

\begin{tabular}{|c|c|c|c|}
\hline $\begin{array}{l}\text { Concentration of } \\
\text { soybean meal }\end{array}$ & $\begin{array}{l}\text { Inhibition zone } \\
\qquad(\mathrm{mm})\end{array}$ & $\begin{array}{l}\text { Concentration of } \\
\text { glucose }\end{array}$ & $\begin{array}{l}\text { Inhibition zone } \\
\qquad(\mathrm{mm})\end{array}$ \\
\hline $1.00 \%$ & 10 & $1.00 \%$ & 10 \\
\hline $1.25 \%$ & 11 & $1.25 \%$ & 11 \\
\hline $1.50 \%$ & 20 & $1.50 \%$ & 20 \\
\hline $1.75 \%$ & 12 & $1.75 \%$ & 12 \\
\hline $2.00 \%$ & 10 & $2.00 \%$ & 11 \\
\hline
\end{tabular}

Table 6. Antibiotic activity of $S$. nigrifaciens (p-9) during fermentation.

Tabla 6. Actividad antibiótica de $S$. nigifaciens (p-9), durante la fermentación.

\begin{tabular}{cc}
\hline Incubation time $(\mathrm{h})$ & Inhibition zone $(\mathrm{mm})$ \\
\hline 24 & - \\
36 & - \\
48 & 7 \\
72 & 9 \\
84 & 10 \\
96 & 14 \\
108 & 10 \\
120 & 8 \\
\hline
\end{tabular}

The antibiotic activity of crude extracts of the isolated strain and type strain are presented in table 7 . The extract of $p-9$ showed very good antibiotic activity against gram positive and gram negative bacteria and did not show any antifungal activity. However, the extract of the type strain showed very little antibacterial activity. This indicates
(Porter, 1975). Los cambios de acidez del medio tienen un efecto importante en la producción final de los productos, que está probablemente relacionada con el incremento de amonio y nitrógeno debido a la descomposición de las proteínas de soja y autólisis del micelio (Egorov, 1985). Entre los solventes usados, el extracto de acetato de etilo mostró 
Table 7. Antibiotic activity of crude extracts of p-9 and type culture.

Tabla 7. Actividad antibiótica de extratos crudos de p-9 y cultivo tipo.

\begin{tabular}{lcc}
\hline Test organisms & \multicolumn{2}{c}{ Width of inhibition zone (mm) } \\
\cline { 2 - 3 } & Type culture & p-9 \\
\hline Bacillus subtilis & 7 & 20 \\
Staphylococcus aureus & 6 & 18 \\
Streptococcus faecalis & 7 & 14 \\
Klebsiella pneumoniae & 8 & 15 \\
Salmonella typhi & 7 & 14 \\
Shigella flexneri & 6 & 16 \\
Vibrio cholerae & 8 & 22 \\
Escherichia coli & 6 & 13 \\
Proteus vulgaris & 6 & 12 \\
Candida albicans & - & - \\
Penicillium restrictum & - & - \\
Fusarium solani & - & - \\
\hline
\end{tabular}

that the antibiotic production is not species specific but strain specific.

It is interesting to note that no antibiotic compound has been isolated so far from S. nigrifaciens, and also that it is the source of choline oxidase enzyme (Manyu Seijaku, 1985), which is useful for the determination of the level of phospholipids in blood serum of patients with such liver complaints as obstructive jaundice. A detailed investigation of the chemical nature and pharmacological activity of the antibiotics generated by $S$. nigrifaciens as well as enzyme studies are suggested for future works.

\section{ACKNOWLEDGEMENTS}

The authors thank the authorities of Annamalai University for the facilities provided. The first author thanks the University Grants Commission and Tamilnadu State Government for a research fellowship.

\section{REFERENCES}

Balagurunathan, R. (1992). Antagonistic marine actinomycetes with special reference to $\alpha \beta$-unsaturated $\gamma$-lactone type of antibiotic from Streptomyces giveobrunneus (P-33). Ph.D. thesis, Annamalai University, India, $72 \mathrm{pp}$. la máxima actividad con 7.0 de $\mathrm{pH}$. Los otros extractos solventes manifestaron actividad muy débil. La extracción fue dependiente del pH en tanto que no hubo actividad más que con $7.0 \mathrm{dc} \mathrm{pH}$.

La actividad antibiótica de los extractos crudos de la cepa aislada y cepa tipo se presentan en la tabla 7. El extracto de p-9 mostró excelente actividad contra bacterias grampositivas y gramnegativas, y no manifestó actividad alguna contra hongos. Sin embargo, el extracto de la cepa tipo tuvo muy poca actividad antibacterial. Esto indica que la producción de antibiótico no es específica de la especie sino de la cepa.

Es interesante anotar que ningún compuesto antibiótico ha sido aislado hasta ahora de $S$. nigrifaciens y, además, que éste es la fuente de enzima colina oxidasa (Manyu Seijaku, 1985), la cual es útil para determinar el nivel de fosfolípidosen el suero sanguíneo de pacientes con problemas hepáticos, como la ictericia obstructiva. Se sugiere, para futuros trabajos, una investigación detallada de la naturaleza química y actividad farmacológica de los antibióticos generados por $S$. nigrifaciens, así como estudios de enzimas.

\section{AGRADECIMIENTOS}

Los autores agradecen, a las autoridades de la Universidad Annamalai, las facilidades 
Balagurunathan and Subramanian: Studies on marine Sireptomyces nigyifaciens (p-9)

Becker, B., Lechevalier, M.P. and Lechevalier, H.A. (1965). Chemical composition of cell wall preparations from strains of various form-genera of aerobic actinomycetes. Appl. Microbiol., 13: 236-243.

Egorov, N.S. (1985). Antibiotic, a scientific approach. MIR publishers, Moscow, $108 \mathrm{pp}$.

Manyu Seijaku, K.K. (1982). Choline oxidase production by fermentation. Patent Japanese Kokai Tokyo Koho IP 57132 880.

Nonamura, H. (1974). Key for the classification and identification of 458 species of streptomycetes included in the ISP. J. Ferment. Technol., 52: 78-92.

Okami, Y. (1986). Marine microorganisms as a source of bioactive agents. Microb. Ecol., 12: 65-78.

Okami, Y., Okazaki, T., Kitahara, T. and Umezawa, H. (1976). A new antibiotic, aplasmomycin produced by a streptomycete isolated from shallow sea mud. J. Antibiot., 29: 1019-1025.

Okami, Y., Hotta, K., Yoshida, M., Ikeda, D., Kondo, S. and Umezawa, H. (1979). New aminoglycoside antibiotics, Istamycin A \& B. J. Antibiot., 32: 964-966.

Okazaki, T. and Okami, Y. (1972). Studies on marine microorganisms. II. Actinomycetes in Sagami Bay and their antibiotic substances. J. Antibiot., 25: 461-466.

Omura, S., Tanaka, Y., Kitao, C., Tanaka, H. and Iwai, Y. (1980). Stimulation of leucomycin production by magnesium phosphate and its relevance to nitrogen catabolite regulation. Antimicrobial Agents and Chemotherapy, 18: 691-695.

Porter, J.N. (1975). Cultural conditions for antibiotic producing microorganisms. In: J.H. Hash (ed.), Methods in enzymology. Vol. XLIII. Antibiotics. Academic Press, New York, pp. 3-23. proporcionadas. El primer autor agradece, a la Comisión de Becas de la Universidad y al Estado de Tamilnadu, el otorgamiento de una beca para investigación. Mora.

Traducido al español por Olivia Gómez

Sambamurthy, K. and Ellaiah, P. (1974). Neomycin (B \& C) production by a new streptomycete species $S$. mainensis. Part II. Hindustan Antibiot. Bull., 17: 41-42.

Shirling, E.B. and Gottileb, D. (1966). Methods for characterization of Streptomyces species. Int. J. Syst. Bacteriol., 16: 313-340.

Shirling, E.B. and Gottileb, D. (1968). Cooperative descriptions of type cultures of Streptomyces. II. Species descriptions from first study. Int. J. Syst. Bacteriol., 18: 69-189.

Suzuki, K., Sako, T., Morioka, M., Nagai, K., Abe, K., Yamaguchi, $H$. and Saito, $T$. (1991). Tetrazomine, a new antibiotic produced by an actinomycete strain. Taxonomy, fermentation, isolation and characterization. J. Antibiot., 44: 479485 .

Takahashi, A., Kurasawa, S., Ikeda, D., Okami, Y. and Takeuchi, T. (1989). Altemicidin, a new acaricidal and antitumor substance. I. Taxonomy, fermentation, isolation and physico-chemical and biological properties. J. Antibiot., 42: 1556-1561.

Waksman, S.A. (1961). The actinomycetes. Vol. II. Williams and Wilkins Co., Baltimore. 